\title{
Dissolved Organic Carbon Cycling in Forested Watersheds: A Carbon Isotope Approach
}

\author{
S. L. Schiff and R. Aravena
}

Waterloo Centre for Groundwater Research and Department of Earth Sciences, University of Waterloo, Waterloo, Ontario, Canada

\author{
S. E. TRUMBorE ${ }^{1}$
}

Institut für Mittelenergiephysik, ETH, Zurich, Switzerland

\section{P. J. DiLLoN}

Dorset Research Centre, Ontario Ministry of the Environment, Dorset, Ontario, Canada

\begin{abstract}
Dissolved organic carbon (DOC) is important in the acid-base chemistry of acid-sensitive freshwater systems; in the complexation, mobility, persistence, and toxicity of metals and other pollutants; and in lake carbon metabolism. Carbon isotopes $\left({ }^{13} \mathrm{C}\right.$ and $\left.{ }^{14} \mathrm{C}\right)$ are used to study the origin, transport, and fate of DOC in a softwater catchment in central Ontario. Precipitation, soil percolates, groundwaters, stream, beaver pond, and lake waters, and lake sediment pore water were characterized chemically and isotopically. In addition to total DOC, isotopic measurements were made on the humic and fulvic DOC fractions. The lake is a net sink for DOC. $\Delta^{14} \mathrm{C}$ results indicate that the turnover time of most of the DOC in streams, lakes, and wetlands is fast, less than 40 years, and on the same time scale as changes in acidic deposition. DOC in groundwaters is composed of older carbon than surface waters, indicating extensive cycling of DOC in the upper soil zone or aquifer.
\end{abstract}

\section{INTRODUCTION}

The importance of dissolved organic carbon (DOC) in the acid-base chemistry of acid-sensitive freshwater systems and in the mobility, persistence, and toxicity of metals and other contaminants in natural waters is now widely recognized. Organic acid anions can contribute up to $20 \%$ of the total acid buffering capacity of lake waters of some acidsensitive lakes [Herczeg et al., 1985]. Because of the low $p \mathrm{~K}_{\mathrm{a}}$ of some of the organic acids (3.5-5.5; [e.g., Eshleman and Hemond, 1985]) these acids can also have an acidifying effect on natural water bodies [Kortelainen and Mannio, 1987; Eshleman and Hemond, 1985; LaZerte and Dillon, 1984]. Dissolved organic carbon is a strong complexing agent for many geochemically important and/or toxic metals such as iron, copper, aluminum, zinc, and mercury. Organically complexed aluminum has been found to be less toxic to aquatic organisms than inorganic forms of aluminum [e.g., Baker and Schofield, 1982]. DOC can increase the weathering rate of minerals [Drever, 1988] and increase the solubility and thus the mobility and transport of many metals and organic contaminants of concern [Stumm and Morgan, 1981].

Despite the importance of DOC in the acid-base chemistry of freshwater systems and in aquatic toxicity studies, very little is known about the production and turnover of DOC within natural watersheds. Investigations of the transport of DOC in soils and DOC budgets in watersheds [e.g., Wallis et al., 1981; LaZerte and Dillon, 1984; Eshleman and Hemond,

\footnotetext{
${ }^{1}$ Now at Center for Accelerator Mass Spectrometry, Lawrence Livermore National Laboratories, Livermore, California.

Copyright 1990 by the American Geophysical Union.

Paper number 90WR01516. 0043-1397/90/90WR-01516\$05.00
}

1985; Dillon et al., 1987; Devito et al., 1990] have yielded insight into the importance and possible sources of DOC. However, studies of DOC concentrations yield no information on the turnover time of DOC produced in the various carbon reservoirs or if the turnover times are influenced by increases or decreases in the deposition of anthropogenic acids. Lake water concentrations of DOC decrease as lakes become progressively acidified [e.g., Davis et al., 1985; Dillon et al., 1987], but the reason is unclear. Predictive models of acid precipitation effects on aquatic systems are hampered by the lack of information on the sources and response of organic acids to changes in the deposition of anthropogenic acids [e.g., Herczeg et al., 1985].

Naturally occurring DOC is a complex composite of molecules and colloids exhibiting a continuous spectrum of sizes and chemical characteristics. To simplify the complexity, natural DOC has been further divided into various fractions (humic and fulvic acids, hydrophobic neutrals and hydrophilic acids, bases, and neutrals) based on chemical reactivity [Thurman, 1984; Bourbonniere, 1989]. Changes in the distribution of the DOC fractions due to differences in relative turnover times will affect the acid-base balance, the complexing ability, and thus the inherent toxicity of these waters to biological organisms. In an alternative scenario for acidification of freshwater systems, Krug and Frink [1983] suggest that as sulfate deposition is decreased, the release of humic acids from the watershed will increase, resulting in little change in the $\mathrm{pH}$ of the receiving water. This hypothesis implies that acid precipitation affects the turnover times of the fractions of DOC.

Our approach involves the use of ${ }^{13} \mathrm{C}$ and ${ }^{14} \mathrm{C}$ measurements to examine the origins and turnover times of DOC in various carbon reservoirs in the watershed of a soft water lake. Until recently, ${ }^{14} \mathrm{C}$ measurements of DOC were not 


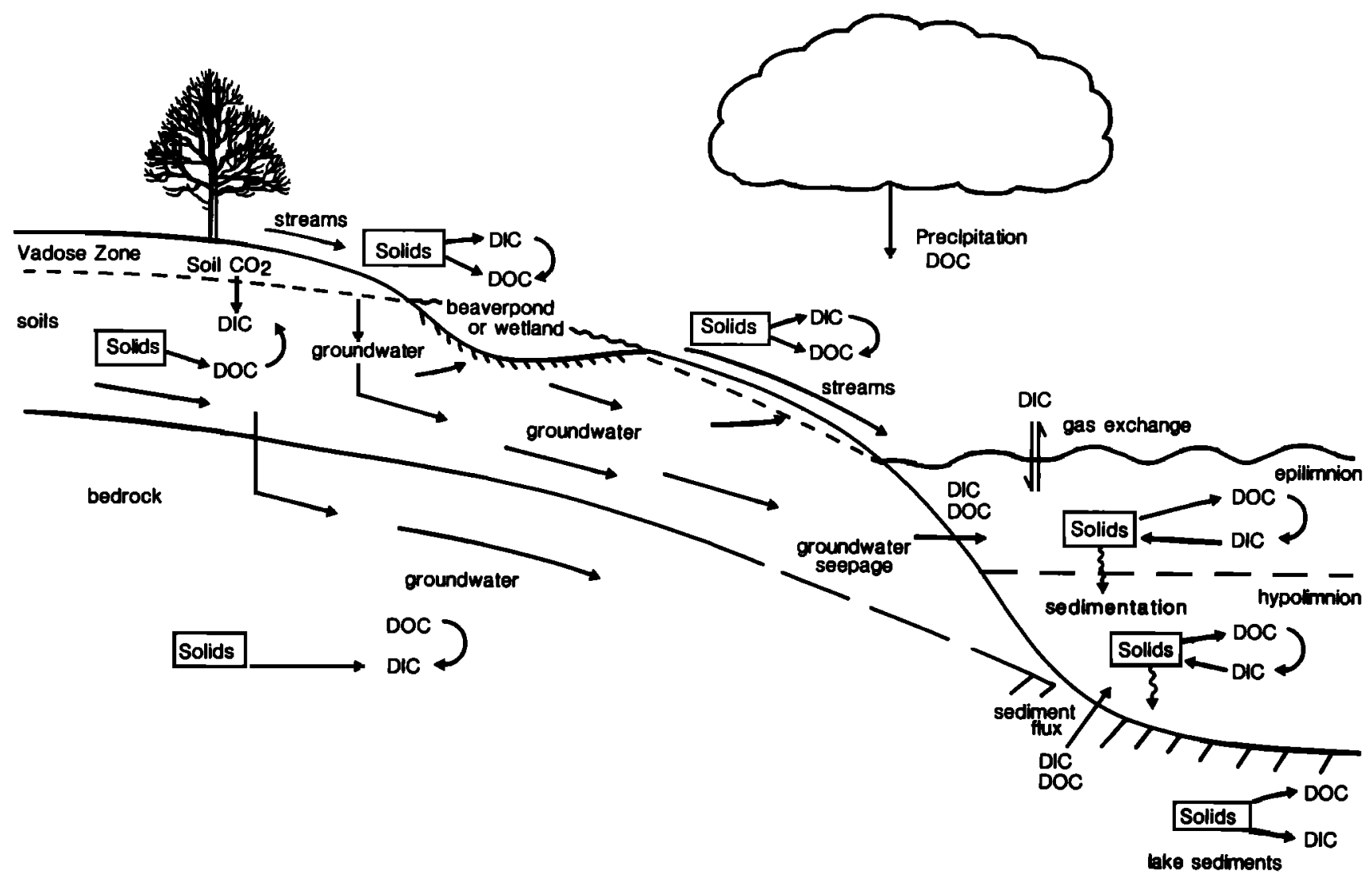

Fig. 1. Carbon cycle in a watershed that does not contain carbonate minerals. DIC is dissolved inorganic carbon and DOC is dissolved organic carbon. The process DIC $\rightarrow$ DOC is referred to as carbon fixation and the process DOC $\rightarrow$ DIC is referred to as mineralization or decomposition.

possible due to the extremely low DOC concentrations in groundwaters and nondystrophic lakes (typically less than 10 $\mathrm{mg} / \mathrm{L}$ ). Recent developments in tandem accelerator mass spectrometry (TAMS) now easily permit the measurement of ${ }^{14} \mathrm{C}$ activity on samples containing $1 \mathrm{mg}$ of carbon. This novel approach has now been used in a few studies concerning DOC cycling in groundwater, rivers, and seawater [Williams et al., 1969; Thurman, 1985; Hedges et al., 1986; Williams and Druffel, 1987; Murphy et al., 1989a, b; Wassenaar et al., 1990] but not to study DOC cycling in lake watersheds.

Our aim was to investigate the sources and transformation of DOC, assess the importance of DOC in lake carbon metabolism, and anticipate potential changes in DOC cycling due to changes in the deposition of strong acids. The research on DOC cycling is part of an extensive investigation of the carbon cycle of soft water lakes. Carbon isotopes $\left({ }^{13} \mathrm{C}\right.$ and ${ }^{14} \mathrm{C}$ ) in conjunction with whole watershed carbon mass balances are being used to evaluate carbon fluxes between the inorganic (atmospheric $\mathrm{CO}_{2}$ and dissolved inorganic carbon (DIC)) and organic carbon pools (DOC and solids) (Figure 1). In this paper, preliminary data collected during the first phase of our research are discussed.

\section{MATERIALS AND METHODS}

\section{Field Sites}

Harp Lake catchment, located in the District of Muskoka, Ontario $\left(45^{\circ} 23^{\prime} \mathrm{N} 7^{\circ} 08^{\prime} \mathrm{W}\right.$; Figure 2$)$, is currently under intensive investigation as part of the Ontario Ministry of the Environment's acidic precipitation research program [Dillon et al., 1980, 1982, 1987; Seip et al., 1985; Devito et al., 1990; Dillon and Molot, 1990]. The catchment has an area of 506 ha and is almost entirely covered by mixed deciduousconifer forest consisting mainly of Acer saccharum (sugar maple), Fagus grandifolia (beech), Betula alleghaniensis (yellow birch), Pinus stobulas (white pine), and Populus tremuloides (aspen). The underlying bedrock composition is predominantly biotite and horneblende gneiss $(68 \%$ of the area), with amphibolite and schist in the western portion of the basin. The overburden consist of a minor till plain ( $>1 \mathrm{~m}$ thick; $50 \%$ of the watershed area) and thin till ( $<1 \mathrm{~m})$ and rock ridges (38\%), with wetlands covering the remainder of the watershed [Jeffries and Snyder, 1983]. Six main tributaries which each drain between 10 and 191 ha feed the lake (Figure 2). The lake has an area of 71.4 ha, a mean depth of $13.2 \mathrm{~m}$, and a maximum depth of $37.5 \mathrm{~m}$. Harp Lake is a soft water lake with an average annual alkalinity of approximately $60 \mu \mathrm{eq} / \mathrm{L}$.

\section{Sampling}

Field activities were initiated during 1988, and samples were collected during spring snowmelt (high flow, low biological activity), midsummer-(low flow, high biological activity), and fall (medium flow). Samples collected for chemical and isotopic characterization of DOC included precipitation, soil LFH, A and B horizon percolates, shallow and deep groundwaters, stream water, beaver pond water, 


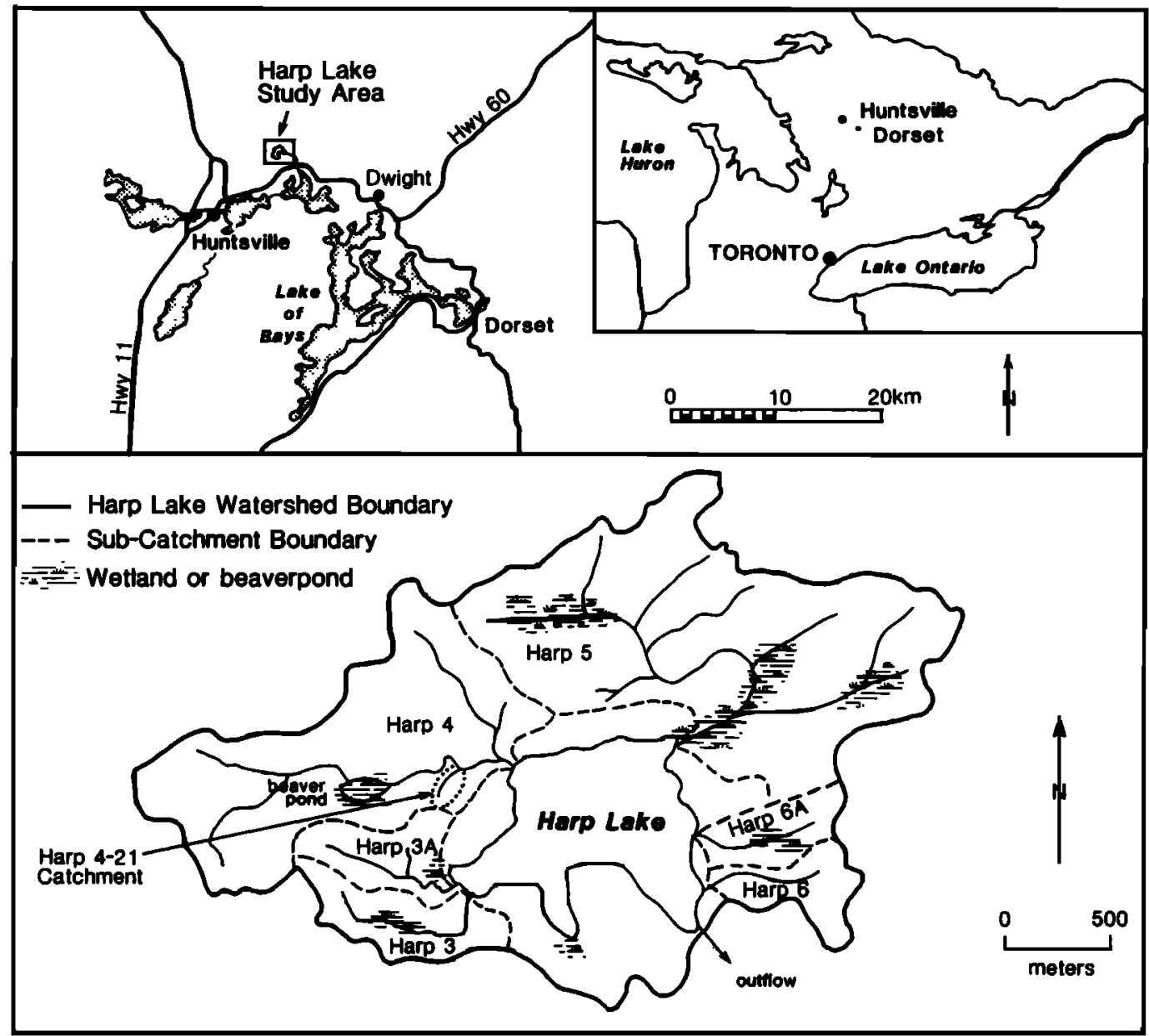

Fig. 2. Location of Harp Lake watershed.

lake water and lake sediment pore water. The soils, soil percolates, and some of the groundwater samples were obtained from Harp 4-21, a small subcatchment of Harp 4 (Figure 2), the site of a detailed ongoing investigation on the importance of the groundwater contribution to the hydrology and geochemistry of a small stream [Dankevy et al., 1990]. Soil organic matter, soil $\mathrm{CO}_{2}$, phytoplankton, and lake sediment cores were also collected to characterize the ${ }^{13} \mathrm{C}$ and ${ }^{14} \mathrm{C}$ content of the potential carbon sources of DOC. All streams were sampled at the gauging weir at the bottom of each subcatchment. The beaver pond in Harp 4 was sampled at the outlet. Soil water was collected from zero-tension lysimeters from the LFH, BHF1, BHF2, and BC soil horizons (B. D. LaZerte, unpublished data, 1989). Lysimeter samples were pooled from the same soil horizons in lysimeters located at differing elevations in the subbasin. Groundwaters were obtained from 2-in-diameter piezometers screened over an interval of $0.6 \mathrm{~m}$ (A. Lye, unpublished data, 1990). Piezometer midscreen depths for piezometers $59,60,61$, and 63 in Harp 4-21 subcatchment are 1.4, 3.25, 3.0 , and $7.0 \mathrm{~m}$, respectively. Piezometers 50 and 55 are located in the Harp 4 subcatchment approximately $15 \mathrm{~m}$ from the shore of Harp Lake and have midscreen depths of 3.0 and $7.3 \mathrm{~m}$, respectively. The bedrock piezometer was installed through the till overburden, sealed with bentonite at the surface and at the bedrock-till interface, and open over an interval of $0.5-3.75 \mathrm{~m}$ below the bedrock-till interface. Suspended lake particulate matter was collected by hauling an $80-\mu \mathrm{m}$ net in the lake epilimnion and thus includes the small amount of detrital material in this size fraction. Lake sediments were collected using a gravity corer and centrifuged to obtain pore waters and solids. Pore waters were subsequently filtered through $0.45-\mu \mathrm{m}$ filters for $\mathrm{DO}^{13} \mathrm{C}$ analyses.

The whole lake mass balance for DOC was constructed from data from all six tributaries which have been continuously gauged since 1976 and sampled, on average, 30-50 times per year during the past 14 years [Dillon et al., 1982]. Bulk precipitation is collected and analyzed on an event basis [Dillon et al., 1988].

\section{Dissolved Organic Carbon}

Single samples of two sizes were collected for $\mathrm{DO}^{13} \mathrm{C}$ and $\mathrm{DO}^{14} \mathrm{C}$ analyses; small volume samples were collected for analysis of total DOC and large samples $(20-100 \mathrm{~L})$ for analysis of DOC fractions. These samples were collected in precleaned glass containers, filtered through 25 - and $0.45-\mu \mathrm{m}$ Balston microfibre filters and acidified to $\mathrm{pH} 2$ with concentrated $\mathbf{H C l}$.

The humic and fulvic acids that are part of the hydrophobic fraction of DOC [Leenheer and Huffman, 1979] were 
TABLE 1a. DOC, $\mathrm{DO}^{13} \mathrm{C}$, and $\mathrm{DO}^{14} \mathrm{C}$ Results Under Low Flow Conditions: August 1988

\begin{tabular}{|c|c|c|c|c|c|c|c|c|}
\hline Sample & $\begin{array}{c}\text { DOC* } \\
\text { mg/L }\end{array}$ & $\begin{array}{c}\text { Hydrophobic } \\
\text { (Percent } \\
\text { DOC) } \dagger\end{array}$ & $\begin{array}{c}\mathrm{DO}^{13} \mathrm{C} \\
\text { Total, } \neq \\
\% o\end{array}$ & $\begin{array}{c}\mathrm{DO}^{13} \mathrm{C} \\
\text { Fulvic, } \ddagger \\
\% 0\end{array}$ & $\underset{\% 0}{\mathrm{DO}^{13} \mathrm{C}} \underset{\text { Humic } \ddagger}{\ddagger}$ & $\begin{array}{c}\mathrm{DO}^{14} \mathrm{C} \\
\text { Total, } \S \\
\% o\end{array}$ & $\begin{array}{c}\mathrm{DO}^{14} \mathrm{C} \\
\text { Fulvic, } \$ \\
\% o\end{array}$ & $\begin{array}{c}\mathrm{DO}^{14} \mathrm{C} \\
\text { Humic, } \$\end{array}$ \\
\hline \multicolumn{9}{|l|}{ 1. Streams and wetlands: } \\
\hline Harp 4 & 12.1 & 74 & -25.9 & -27.0 & -27.1 & $+131 \pm 9$ & $+217 \pm 9$ & $+42 \pm 8$ \\
\hline Harp 4-21 & 11.0 & 72 & $\cdots$ & $\cdots$ & $\cdots$ & $\cdots$ & $\cdots$ & $\cdots$ \\
\hline Harp 5 & 20.0 & 64 & -26.6 & $\cdots$ & $\cdots$ & $\cdots$ & $\cdots$ & $\ldots$ \\
\hline Harp 3A & 2.0 & 74 & -24.8 & -27.3 & -26.0 & $+187 \pm 9$ & $+127 \pm 9$ & $+99 \pm 9$ \\
\hline Harp $4-$ Beaverpond & 6.5 & 64 & -27.1 & -27.6 & -29.1 & $+98 \pm 9$ & $+90 \pm 7$ & ... \\
\hline $\begin{array}{l}\text { 2. Precipitation } \\
\text { 3. Harp Lake }\end{array}$ & \multicolumn{7}{|c|}{ 3. Harp Lake } & $\cdots$ \\
\hline Epilimnion & 4.0 & 55 & -25.7 & -26.9 & -26.2 & $+158 \pm 9$ & $+136 \pm 9$ & $+99 \pm 9$ \\
\hline Hypolimnion & 2.9 & 46 & -24.9 & -27.0 & -27.0 & $+116 \pm 9$ & $+136 \pm 9$ & $+110 \pm 9$ \\
\hline \multicolumn{9}{|l|}{ 4. Groundwaters } \\
\hline Piezometer 55 & 1.0 & $\cdots$ & $\cdots$ & -27.0 & -27.4 & $\cdots$ & $-116 \pm 6$ & $\cdots$ \\
\hline Piezometer 50 & 1.5 & 66 & $\cdots$ & -27.6 & $\cdots$ & $\cdots$ & $\cdots$ & $\cdots$ \\
\hline Piezometer 59 & 0.8 & 31 & $\cdots$ & -27.0 & $\cdots$ & $\ldots$ & $+13 \pm 7$ & $\cdots$ \\
\hline Piezometer 60 & $\cdots$ & 55 & $\cdots$ & -25.7 & $\cdots$ & $\cdots$ & $-122 \pm 5$ & $\ldots$ \\
\hline \multicolumn{9}{|l|}{ 5. Miscellaneous samples } \\
\hline Sediment porewater $(0-10 \mathrm{~cm})$ & ... & & -29.5 & $\cdots$ & $\cdots$ & $\ldots$ & $\ldots$ & $\ldots$ \\
\hline Suspended lake particulates & $\cdots$ & & -29.8 & $\cdots$ & $\cdots$ & $\cdots$ & $\cdots$ & $\cdots$ \\
\hline Sediment solids $(0-1 \mathrm{~cm})$ & $\cdots$ & & -27.9 & $\cdots$ & $\cdots$ & & & \\
\hline Sediment solids $(20-25.5 \mathrm{~cm})$ & $\cdots$ & & -27.6 & $\ldots$ & $\cdots$ & & & \\
\hline
\end{tabular}

*Analytical reproducibility in DOC is approximately $0.15 \mathrm{mg} / \mathrm{L}$ in the range $0-4 \mathrm{mg} / \mathrm{L} \mathrm{DOC}$ and $0.10 \mathrm{mg} / \mathrm{L}$ in the range $4-20 \mathrm{mg} / \mathrm{L} \mathrm{DOC}$. $\nmid$ Reproducibility is approximately $5 \%$.

$\neq D O^{13} \mathrm{C}$ values are reported in $\partial^{13} \mathrm{C} \%$. Precision for ${ }^{13} \mathrm{C}$ analyses was $\pm 0.05 \%$, and sample reproducibility was better than $\pm 0.2 \%$.

$\$ D 0^{14} \mathrm{C}$ values are reported in $\Delta{ }^{14} \mathrm{C} \%$. Precision for individual ${ }^{14} \mathrm{C}$ analysis by TAMS is indicated above. Sample reproducibility was better than $10 \%$ for our samples and in other studies of groundwater DOC covering a wide range of ${ }^{14} \mathrm{C}$ activities [Wassenaar, 1990].

isolated by sorption on Amberlite XAD-8 ${ }^{\mathrm{TM}}$ at $p \mathrm{H} 2$ [Thurman and Malcolm, 1981]. After elution and acidification to separate humic and fulvic acids, these samples were freezedried and stored in glass containers. The hydrophobic/ hydrophilic split was calculated by difference between the DOC concentration before and after the sample had passed through the XAD column. A detailed description of the methods and equipment used for the DOC fractionation can be found in the thesis by Wassenaar [1990]. For recovery of total DOC the samples were freeze-dried. Any volatile organic compounds in both the total DOC and the DOC fractions would have been lost. Note that different researchers employ different definitions of the operationally separated DOC fractions and that these definitions are not always transferable. Comparison of the definitions for the various DOC fractions can be found in the paper by Bourbonniere [1989].

Measurements of DOC concentrations were performed by a combination UV-chemical oxidation method at the Ontario Ministry of the Environment [1989] except for DOC analyses required during the DOC separation procedure to quantify the hydrophobic/hydrophilic fractions that were measured at the University of Waterloo using a Dohrmann organic carbon analyzer.

\section{Carbon Isotope Analyses}

Aliquots of dry humic, fulvic, and total DOC samples were combusted in a pure oxygen atmosphere, and the resulting $\mathrm{CO}_{2}$ was trapped and purified cryogenically for ${ }^{14} \mathrm{C}$ and ${ }^{13} \mathrm{C}$ analyses. $\mathrm{CO}_{2}$ was âlso prepared by combuistion of samples at $550^{\circ} \mathrm{C}$ in breakseals using copper oxide and silver wire [Boutton et al., 1983]. Analyses of ${ }^{13} \mathrm{C}$ were done on a VG Micromass 903 triple collecting mass spectrometer at the Environmental Isotope Laboratory, University of Waterloo, and reported using the $\partial$ notation relative to the international Pee Dee Belemnite (PDB) standard, where

$$
\partial^{13} \mathrm{C}=\left[\left(R_{\text {sample }} / R_{\text {standard }}\right)-1\right] * 1000
$$

(in \%o), and $R$ is the ${ }^{13} \mathrm{C} /{ }^{12} \mathrm{C}$ ratio in the sample or standard.

Radiocarbon analyses were done by direct counting of ${ }^{14} \mathrm{C}$ atoms by the TAMS facility in Zurich, Switzerland [Suter et $a l ., 1983]$, and at the Isotrace Laboratory of the University of Toronto [Kieser et al., 1986]. ${ }^{14} \mathrm{C}$ results are expressed in delta per mil $\left(\Delta^{14} \mathrm{C}\right)$ relative to $95 \%$ of the activity of oxalic acid standard in 1950 and normalized to a $2{ }^{13} \mathrm{C}$ of $-25 \%$ PDB [Stuiver and Polach, 1977].

\section{Results AND Discussion}

\section{DOC Concentrations and Mass Balances}

Concentrations of DOC in samples collected during low flow conditions (August 1988) and high flow conditions (April 1989) are given in Table 1. Although Table 1 contains the DOC concentrations analyzed in the samples collected for isotopic analyses, these values are representative of samples collected biweekly for at least 2 years (14 years for major inflows) for high and low flow periods (P. J. Dillon, unpublished data, 1990). Groundwaters and precipitation exhibit the lowest DOC concentrations; lake waters, although higher in DOC than groundwaters, are lower than most stream inflows.

At low flow, the DOC concentration of the stream in the small upland basin Harp 4-21 which contains no wetland areas was much higher than in groundwaters or soil B horizon percolates collected at high flow (Table 1b). This area experienced a drought in the summer of 1988, receiving no substantial rainfall for the 3 months preceeding the sampling date, and the resultant water table levels in the 
TABLE $1 b$. DOC, DO ${ }^{13} \mathrm{C}$, and $\mathrm{DO}^{14} \mathrm{C}$ Results Under High Flow Conditions: April 1989

\begin{tabular}{|c|c|c|c|c|c|}
\hline Sample & $\begin{array}{l}\text { DOC*, } \\
\text { mg/L }\end{array}$ & $\begin{array}{l}\text { Hydrophobic } \dagger \\
\text { (\%DOC) }\end{array}$ & $\begin{array}{l}\text { Hydrophilic } \dagger \\
\text { (\%DOC) }\end{array}$ & $\begin{array}{c}\mathrm{DO}^{13} \mathrm{C} \\
\text { Total, } \ddagger\end{array}$ & $\begin{array}{c}\mathrm{DO}^{14} \mathrm{C} \\
\text { Total, } \S\end{array}$ \\
\hline \multicolumn{6}{|l|}{ 1. Streams and wetlands } \\
\hline Harp 4 & 4.1 & 52 & $\cdots$ & -27.0 & $+21 \pm 13$ \\
\hline Harp 4-21 & 3.5 & $\cdots$ & 5 & -31.4 & $-44 \pm 8$ \\
\hline Harp 5 & 5.4 & 52 & 22 & -28.4 & $+139 \pm 8$ \\
\hline Harp 3A & 3.3 & 47 & 5 & -29.7 & $+139 \pm 9$ \\
\hline Harp 4-Beaverpond & 4.7 & $\cdots$ & ... & -40.2 & $\ldots$ \\
\hline 2. Harp Lake (May 1989) & 3.6 & 50 & 28 & -27.9 & $+87 \pm 14$ \\
\hline \multicolumn{6}{|l|}{ 3. Groundwaters } \\
\hline Piezometer 59 & 0.9 & $\cdots$ & $\cdots$ & -30.3 & $-39 \pm 33$ \\
\hline Piezometer 60 & 4.1 & $\cdots$ & $\cdots$ & -26.5 & $\cdots$ \\
\hline \multicolumn{6}{|l|}{ 4. Soil percolates } \\
\hline LFH & 17.5 & $\cdots$ & $\cdots$ & -27.5 & $+95 \pm 8$ \\
\hline BHF1 & 4.2 & $\cdots$ & $\cdots$ & -28.9 & $+74 \pm 7$ \\
\hline BHF2 & 3.2 & $\cdots$ & $\cdots$ & -30.9 & $+95 \pm 7$ \\
\hline $\mathrm{BC}$ & 2.7 & $\cdots$ & $\cdots$ & -31.0 & $\cdots$ \\
\hline
\end{tabular}

*Analytical reproducibility in DOC is approximately $0.15 \mathrm{mg} / \mathrm{L}$ in the range $0-4 \mathrm{mg} / \mathrm{L} \mathrm{DOC}$ and $0.10 \mathrm{mg} / \mathrm{L}$ in the range $4-20 \mathrm{mg} / \mathrm{L} \mathrm{DOC}$. $\uparrow$ Reproducibility is approximately $5 \%$.

$\ddagger D{ }^{13} \mathrm{C}$ values are reported in ${ }^{13} \mathrm{C} \%$. Precision for ${ }^{13} \mathrm{C}$ analyses was $\pm 0.05 \%$, and sample reproducibility was better than $\pm 0.2 \%$.

$\S \mathrm{DO}{ }^{14} \mathrm{C}$ values are reported in $\Delta{ }^{14} \mathrm{C} \%$. Precision for individual ${ }^{14} \mathrm{C}$ analysis by TAMS is indicated above. Sample reproducibility was better than $10 \%$ for our samples and in other studies of groundwater DOC covering a wide range of ${ }^{14} \mathrm{C}$ activities [Wassenaar, 1990].

basin were very low. The stream at this time was still flowing and thus must have been fed by a deeper groundwater source [Dankevy et al., 1990]. Because groundwater DOC concentrations are so low, the high stream DOC at low flow periods, especially in basins such as Harp 4-21, points to the presence of an instream source of DOC during summer months or the presence of an organic-rich layer immediately adjacent to the streams through which the discharging groundwater percolates. In contrast, Harp $3 \mathrm{~A}$ (Figure 2) drains a catchment containing no wetlands but has a low summer DOC concentration, indicating that the instream or near-stream DOC source is not ubiquitous.

Harp 5, which constitutes $40 \%$ of the terrestrial watershed and contains a large wetland area (Figure 2), exhibits higher DOC concentrations than other inflowing streams (1-2 mg/L higher in high flow and 8-18 mg/L higher in low flow). As a result, Harp 5 is the major contributor of terrestrial-source DOC to the lake (Table 2). Although wetlands and swamps can contribute a large supply of DOC to stream water, there is no net production of DOC by the beaver pond in Harp 4 [Devito et al., 1990]. Instead, the beaver pond appears to temporally moderate DOC output from upbasin areas. Both Harp 4 and Harp 4-21, the small upland subcatchment containing no wetland areas, had almost twice the DOC concentrations under summer low flow conditions as the beaver pond outflow (Table $1 a$ ). In contrast, the beaver pond DOC values were slightly higher than Harp 4 streams during high flow (Table $1 b$ ).

For DOC in Harp Lake, an annual whole lake mass balance can be constructed:

$$
\begin{aligned}
d \mathrm{DOC}_{/} / d t= & Q_{\mathrm{pptn}} \mathrm{DOC}_{\mathrm{pptn}}+\Sigma Q_{\mathrm{in}} \mathrm{DOC}_{\text {in }} \\
& +\Sigma \mathrm{Q}_{\mathrm{gw}} \mathrm{DOC}_{\mathrm{gw}}-Q_{\text {out }} \mathrm{DOC}_{\text {out }}+F_{\text {pore }} \\
& +F_{\text {phyto }}-F_{\text {decomp }}-F_{\text {sed }}
\end{aligned}
$$

where $\mathrm{DOC}_{x}$ is DOC concentration in the water $(\mathrm{mg} / \mathrm{L}), Q_{x}$ is annual hydrologic flux to/from Harp Lake $\left(\mathrm{m}^{3} / \mathrm{yr}\right)$, and $\boldsymbol{F}_{x}$ is annual rate of DOC transformation within Harp Lake (mg/yr). The subscripts pptn, in, gw, and out refer to bulk precipitation, stream inflows, direct groundwater seepage into the lake in both gauged and ungauged areas, and the lake outflow, respectively. The subscripts pore, phyto, decomp and sed refer to the diffusive pore water flux from lake sediments, phytoplankton (and zooplankton) release, in-lake decomposition by microbial or photooxidative processes and gross in-lake sedimentation. Because the lake is at steady state with respect to DOC on an annual basis [Dillon et al., 1987], the above equation must equal zero if all the important terms have been included. The magnitude of the terms: phytoplankton release, decomposition, and sedimentation,

\begin{tabular}{|c|c|c|}
\hline Parameter & Location & Value \\
\hline $\begin{array}{l}\mathrm{DOC}, 10^{9} \mathrm{mg} / \mathrm{yr} \\
\text { Inflows }\left(\Sigma Q_{\mathrm{in}} \mathrm{DOC}_{\mathrm{in}}\right)\end{array}$ & $\begin{array}{l}\text { Harp 3 } \\
\text { Harp 3A } \\
\text { Harp } 4 \\
\text { Harp } 5 \\
\text { Harp 6 } \\
\text { Harp 6A } \\
\text { ungauged* }\end{array}$ & $\begin{array}{r}1.19 \\
0.41 \\
4.11 \\
11.86 \\
0.37 \\
0.58 \\
3.56\end{array}$ \\
\hline $\begin{array}{l}\text { Precipitation }\left(Q_{\mathrm{pptn}} \mathrm{DOC} C_{\mathrm{pptn}}\right) \\
\text { Outflow }\left(Q_{\text {out }} \mathrm{DOC} \mathrm{C}_{\text {out }}\right) \\
\text { Net in-lake flux } \dagger(\Sigma F)\end{array}$ & & $\begin{array}{r}0.85 \\
13.29 \\
10.65\end{array}$ \\
\hline $\begin{array}{l}\text { Outflow discharge }\left(Q_{\text {out }}\right), 10^{9} \mathrm{~L} / \mathrm{yr} \\
\text { Average outflow DOC } \\
\left(\mathrm{DOC}_{\text {out }}\right), \mathrm{mg} / \mathrm{L} \neq\end{array}$ & & $\begin{array}{l}3.16 \\
4.20\end{array}$ \\
\hline $\begin{array}{l}\text { Theoretical lake outflow DOC } \\
\text { concentration, mg/L\$ }\end{array}$ & & 7.26 \\
\hline
\end{tabular}

TABLE 2. Mass Balance of DOC at Harp Lake Watershed: 1978-1988

Definitions of symbols and subscripts are given in text.

*Not including ungauged flow via direct seepage of groundwater into the lake in the numbered catchments (Figure 2).

†Equation (2) in text and assuming groundwater DOC contribution $\left(Q_{\mathrm{gw}} \mathrm{DOC}_{\mathrm{gw}}\right)$ is negligible.

$\mp$ Calculated by dividing the outflow DOC $\left(10^{9} \mathrm{mg} / \mathrm{yr}\right)$ by the outflow discharge $\left(10^{9} \mathrm{~L} / \mathrm{yr}\right)$.

§Equation (3) in text. 
are difficult to measure directly. However, since $d \mathrm{DOC}_{l} / d t$ $=0$ at steady state, the net importance of these flux terms can be quantified by rearrangement of (1):

$$
\begin{aligned}
\Sigma F= & -F_{\text {pore }}-F_{\text {phyto }}+F_{\text {decomp }}+F_{\text {sed }} \\
\Sigma F= & Q_{\text {pptn }} \mathrm{DOC}_{\text {pptn }}+\Sigma Q_{\text {in }} \mathrm{DOC}_{\text {in }}+\Sigma Q_{\mathrm{gw}} \mathrm{DOC}_{\mathrm{gw}} \\
& -Q_{\text {out }} \mathrm{DOC}_{\text {out }}
\end{aligned}
$$

For $\Sigma F>0$, the lake is a net sink for DOC originating in the terrestrial basin while for $\Sigma F<0$ the lake is a net source of DOC.

The hydrologic contribution from direct groundwater seepage is also difficult to quantify. The contribution from ungauged areas of the basin has been calculated by assuming an identical proportional contribution of flow and base flow DOC contribution, as was obtained in a gauged area. Recent work (A. Lye, unpublished data, 1990; J. Wills, unpublished data, 1990) has shown that up to an additional $5 \%$ of the annual streamflow could be entering the lake as direct groundwater seepage in some gauged areas. However, since groundwater DOC concentrations are so low (Table 1), and the annual water budget of Harp Lake ignoring groundwater sources and losses is balanced to within an average of $3 \%(\mathrm{P}$. J. Dillon, unpublished data, 1989), contribution of DOC from seepage of groundwater directly into Harp Lake will likely be small (probably less than 5\%) compared to the major inflows.

Mass balances constructed for the past 10 years for Harp Lake (Table 2) demonstrate that the lake is a net sink for DOC $(\Sigma F>0)$. Thus although direct groundwater seepage, phytoplankton release, and sediment pore water flux must also add DOC to the lake water, decomposition and sedimentation of DOC must be substantial to far outweigh both the in-lake DOC sources and the allochthonous DOC sources, since the lake is at steady state. The theoretical lake outflow DOC concentration, ignoring groundwater contributions and in-lake production,

$$
\mathrm{DOC}_{\text {out }}=\left(Q_{\mathrm{pptn}} \mathrm{DOC}_{\mathrm{pptn}}+\Sigma Q_{\text {in }} \mathrm{DOC}_{\text {in }}\right) / Q_{\text {out }}
$$

averages $7.3 \mathrm{mg} / \mathrm{L}$ (Table 2), in comparison with the observed average annual lake outflow value of $4.2 \mathrm{mg} / \mathrm{L}$, illustrating the importance of the in-lake DOC removal mechanisms.

\section{DOC Fractions}

In general, the hydrophobic fraction (including acids, bases, and neutrals) constitutes between 45 and $75 \%$ of the total DOC (Table 1). The percent hydrophobic is slightly lower in the lake and groundwater than the streams and is lower in the streams at high flow conditions (April 1989) in comparison with low flow conditions (August 1988). The range for percent hydrophobic is similar to data reported by Thurman [1985], Bourbonniere [1989], and Wassenaar et al. [1990] for surface waters and groundwaters.

The hydrophilic low molecular weight (LMW) fraction constitutes between 5 and $28 \%$ of the total DOC (Table 1), but there is not sufficient data to permit generalizations. If the neutral fraction of the hydrophobic component which is retained on the $\mathrm{XAD}$ column constitutes at most $15 \%$ [Bourbonniere, 1989], then at most $30-60 \%$ of the DOC has not been isolated in our humic acid, fulvic acid, and hydrophilic LMW fractions and, consequently, is not available for

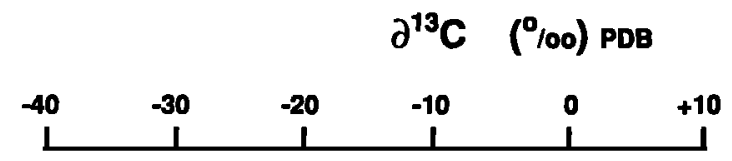

H atmospheric $\mathrm{CO}_{2}$

carbonate rocks $\longmapsto$
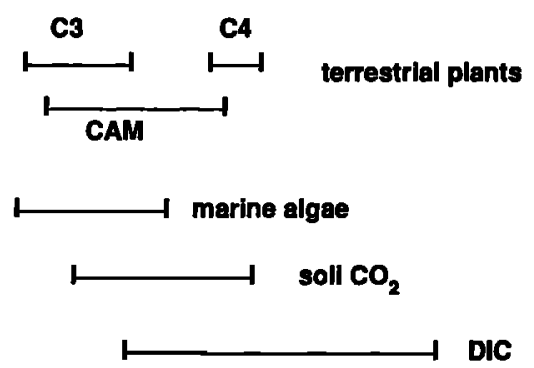

freshwater lakes

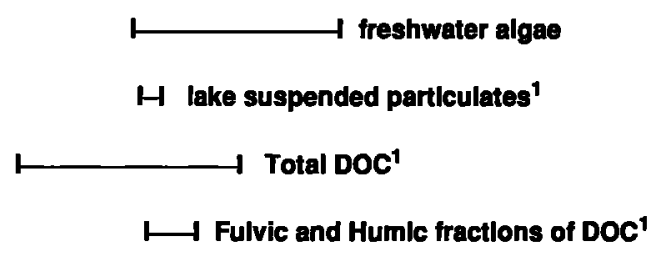

Modifled from Deines (1980).

1. This study.

Fig. 3. Average expected and observed ranges of $\partial^{13} \mathrm{C}$.

carbon isotope analyses. Further studies to more completely characterize the DOC fractions are planned.

\section{$D O^{13} C$ Results}

Ranges of expected $\partial^{13} \mathrm{C}$ of DOC precursors, terrestrial $\mathrm{C}_{3}$ plants, and aquatic phytoplankton overlap (Figure 3 ). Measured total $\mathrm{DO}^{13} \mathrm{C}$ in streams and lakewaters at Harp Lake Watershed fall within these expected ranges of $-24 \%$ to $-31 \%$ (Table 1 ), and thus it is not surprising that stream inflows and lake $\mathrm{DO}^{13} \mathrm{C}$ values are similar. Suspended lake particulates and the DOC in upper sediment pore waters are $1.6-4.9 \%$ lighter in $\partial^{13} \mathrm{C}$ than lake water $\mathrm{DOC}$, but as anticipated, the isotopic separations are not large. In addition, some seasonal variability to the $\partial^{13} \mathrm{C}$ signatures is evident. Summer low flow $\partial^{13} \mathrm{C}$ values in the streams, beaver pond, and lake (August 1988) are on average 1-3\%o heavier than spring peak flow values. Beaver pond water is lighter in $\partial^{13} \mathrm{C}$ than the streams in both low and high flow periods, indicating that processes affecting DOC production and turnover differ between the beaver pond and the streams. To obtain information on DOC cycling from $\partial^{13} \mathrm{C}$ measurements and to separate autochthonous and allochthonous DOC sources to the lake will require careful evaluation of small seasonal variations and other potential sources of variability in ${ }^{13} \mathrm{C}$ values. Although the seasonal variations are significant and thus the associated errors may be large, calculation of the lake water $\mathrm{DO}^{13} \mathrm{C}$ by $\mathrm{DO}^{13} \mathrm{C}$ mass 


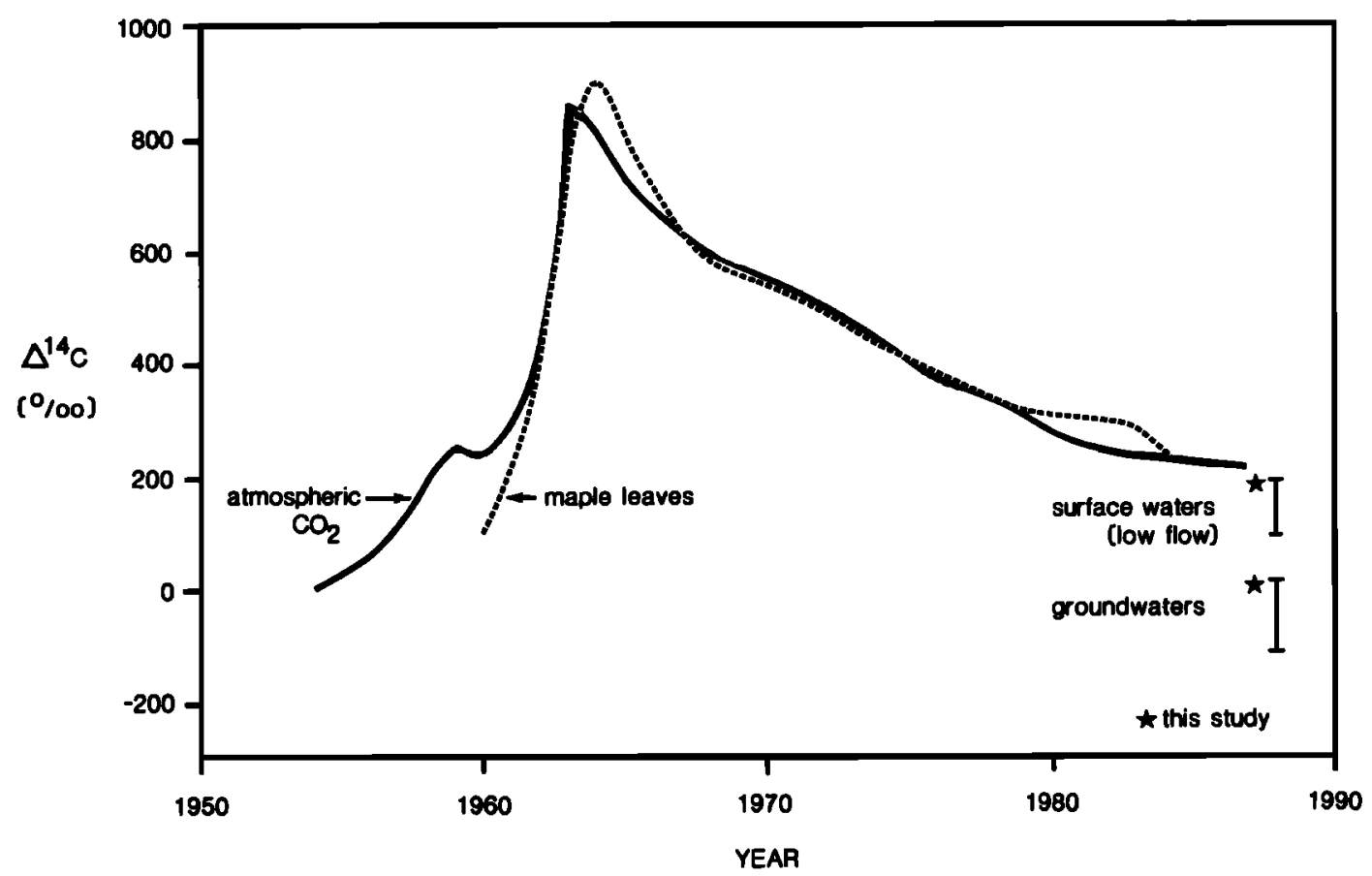

Fig. 4. Temporal trend of atmospheric $\Delta{ }^{14} \mathrm{C}$ in the northern hemisphere. The record from maple leaves for the years 1960-1986 was obtained from Gatineau Park, Quebec, Canada [McNeely, 1988]. The atmospheric $\mathrm{CO}_{2}$ record is modified from Tans [1981] and Manning et al. [1990].

balance (equation (3)) using a discharge-weighted average of high and low flow $\mathrm{DO}^{13} \mathrm{C}$ and $\mathrm{DOC}$ agrees within the seasonal range of observed lake water $\mathrm{DO}^{13} \mathrm{C}$ values. Large excursions in seasonal $\partial^{13} \mathrm{C}$ signatures or large isotopic effects associated with the unknown in-lake transformation terms $F_{\text {pore }}, F_{\text {phyto }}, F_{\text {decomp }}$, and $F_{\text {sed }}$ are unlikely.

The $\partial^{13} \mathrm{C}$ of the total DOC becomes increasingly lighter as the soil water percolates downward through the soil horizons and enters the saturated zone (Table $1 b$ ). Oxidation and sorption of DOC in the soil horizons, which result in the large decrease in DOC concentrations from upper LFH soil percolates to groundwaters, appears to have associated $\partial^{13} \mathrm{C}$ isotopic effects (LFH to BC horizon: -27.5 to $-31.0 \%$; Table $1 b$ ), possibly due to preferential decomposition or sorption of selected compounds.

The ${ }^{13} \mathrm{C}$ values of the humic and fulvic fractions of DOC, with the exception of the precipitation sample, are generally $1-3 \%$ lighter than the total $\mathrm{DO}^{13} \mathrm{C}$ (Table 1).

\section{DO ${ }^{14} \mathrm{C}$ Results}

The DOC produced and flushed from the watershed is a mixture of compounds with varying ${ }^{14} \mathrm{C}$ contents depending on the DOC parent material and the residence time in the aquifer in the case of groundwaters. Hydrogeologic studies in the Harp 4-21 subcatchment area estimated an average groundwater residence time of approximately 4 years [Dankevy et al., 1990]. Although the groundwater residence time within the entire Harp 4 catchment will be longer than in Harp 4-21, all waters in the basin including shallow and deep groundwater and groundwater from a bedrock well are tritiated at levels substantially above background cosmogenic tritium levels, indicating that the average water residence time must be less than 35 years (R. Aravena, unpublished data, 1989). Thus the $\mathrm{DO}^{14} \mathrm{C}$ values reflect the average DOC production and turnover time scale and not the age of a DOC reservoir, because the watershed is being continuously flushed of DOC on a time scale that is essentially instantaneous compared to the radio decay half-life of ${ }^{14} \mathrm{C}$.

In general, the $\Delta^{14} \mathrm{C}$ values of all surface water samples including streams, lakes, and wetlands are greater than $0 \%$ (Table 1). Because atmospheric $\mathrm{CO}_{2}$ prior to the atmospheric testing of nuclear devices (starting in 1952) has a $\Delta^{14} \mathrm{C}$ equal to or less than $0 \%$, surface water DOC must contain a substantial amount of bomb carbon. If all the DOC is not manufactured from carbon pools originating during one specific year (e.g., not all carbon sources have peak bomb values of 1963-1964; Figure 4), then on average at least $50 \%$ of the DOC in these surface water samples (except Harp 4 and Harp 4-21 in the high flow period) is bomb carbon. This high ${ }^{14} \mathrm{C}$ activity in DOC shows that cycling of a significant portion of the DOC in natural watersheds occurs on a short time scale (less than $\mathbf{4 0}$ years) and on a time scale comparable to some anthropogenic perturbations such as increases in acidic deposition. Because the turnover time of DOC is short, the potential exists for anthropogenic activities to alter the turnover rate or transport of DOC and consequently the acid-base chemistry of waters and the mobility, toxicity, or persistence of metal or organic contaminants. Because no $\Delta^{14} \mathrm{C}$ measurements have previously been made on DOC, the production time of DOC in natural watersheds was unknown.

$\Delta^{14} \mathrm{C}$ measurements on DOC fractions indicate that aquatic humic substances contain less bomb carbon and thus are probably more refractory than aquatic fulvic acids. The younger age of fulvics compared to humics had previously been inferred from the change in number and types of 
functional groups on aquatic fulvics versus humic acids [e.g., Thurman, 1985]. These $\Delta{ }^{14} \mathrm{C}$ results in aquatic humic and fulvic acids are compatible with ${ }^{14} \mathrm{C}$ dating of fulvic and humic acids extracted from soil organic matter [Paul and Van Veen, 1978; O'Brien and Stout, 1978]. In addition, the total $\mathrm{DO}^{14} \mathrm{C}$ in Harp 3A inflow and the Harp Lake epilimnion contains more bomb carbon than either the fulvic or humic fraction, suggesting the presence of a rapidly cycling component not captured in the fulvic or humic acid fraction. Further work on DOC fractionation is needed to identify and investigate the chemical characteristics of this labile fraction.

Harp 4 (with wetlands and beaver ponds) has lower DO ${ }^{14} \mathrm{C}$ than Harp 3A (no wetlands), and the Harp 4 beaver pond has low $\mathrm{DO}^{14} \mathrm{C}$ in the fulvic acid fraction compared to all other surface water samples, suggesting that environments accumulating carbon such as wetlands release slightly older DOC or more reworked carbon than the DOC resulting from in-stream or near-stream production.

Whereas surface water DOC samples all contain a significant portion of bomb carbon, DOC in shallow and deeper groundwaters has an average age substantially older than modern carbon of 1950 . The higher groundwater $\Delta{ }^{14} \mathrm{C}$ value was observed in shallow groundwater from the recharge areas in Harp 4-21 (piezometer 59), and the lower values were obtained from deeper piezometers. The presence of older carbon even in shallow groundwaters indicates that the groundwater DOC is not simply a small unfractionated percentage of the total DOC that bypassed the DOC oxidation, sorption, and precipitation processes in the soil horizons but must be DOC that has undergone extensive cycling in the upper soil zone or the aquifer. Similar ${ }^{14} \mathrm{C}$ trends have been documented in three differing shallow groundwater aquifers by Wassenaar et al. [1990].

Selective loss of modern carbon in the soil zone is not supported by the soil lysimeter data (Table $1 b$ ). Lysimeters sample more localized flow pathways, whereas groundwater piezometers integrate upbasin processes affecting DOC. Further work on temporal trends in lysimeter data and analysis of samples from upbasin piezometers and single lysimeter pits instead of combined samples may clarify the isotopic evolution of DOC in these groundwaters.

During high flow (April 1989), stream water has a lower $\Delta^{14} \mathrm{C}$ than in low flow (August 1988). Since groundwater also has low $\Delta{ }^{14} \mathrm{C}$, the low $\Delta{ }^{14} \mathrm{C}$ in stream water during high flow (peak snowmelt) may reflect a larger proportion of older groundwater DOC compared to younger in-stream or nearstream DOC production in late summer.

In Harp Lake the total $\Delta^{14} \mathrm{C}$ of the DOC is higher in the epilimnion than in the hypolimnion, yet the fulvic and humic acid fractions retain the same $\Delta{ }^{14} \mathrm{C}$ in both the epilimnion and hypolimnion. Since the total DOC concentrations decrease in the hypolimnion relative to the epilimnion, and the $\Delta^{14} \mathrm{C}$ in the epilimnetic total DOC is higher than in the fulvic and humic acid fractions, it appears that the DOC fraction containing the most bomb carbon might be rapidly decomposed (i.e., since spring overturn) in the hypolimnion, resulting at least in part, in lower DOC concentrations. Another possible explanation for this set of observations is that all the DOC fractions degrade in the hypolimnion in equal proportions but that the hypolimnetic sediment pore water flux adds substantially to the hypolimnetic DOC pool and is composed of older carbon in a DOC fraction that is not operationally separated as fulvic or humic acids. A third possibility is that decomposition of terrestrial-source DOC within the lake is substantial and that phytoplankton release significant quantities of young carbon that is not separated in the humic and fulvic fractions. This autochthonous source of DOC increases the $\Delta^{14} \mathrm{C}$ and concentration of DOC in the lake epilimnion in comparison to the hypolimnion but must be readily metabolized on the time scale of semiannual lake turnovers to prevent the buildup of younger DOC in the lake. Analyses of the $\mathrm{DO}^{14} \mathrm{C}$ in the pore waters currently underway and further work planned on discerning shifts in the percentage of DOC contained in each of the DOC fractions coupled with $\Delta^{14} \mathrm{C}$ measurements should differentiate between these possibilities.

\section{CONCLUSIONS}

Harp Lake is a net sink for DOC. The observed average annual lake outflow DOC concentration is only $60 \%$ of the theoretical minimum value calculated from known contributions by precipitation and inflows.

Carbon isotopes, ${ }^{13} \mathrm{C}$ and ${ }^{14} \mathrm{C}$, are useful tools for investigating DOC cycling in forested watersheds.

One of the most important findings of this research is the fast turnover time for DOC in natural watersheds. The $\Delta{ }^{14} \mathrm{C}$ activity of DOC in streams, lakes, and wetlands shows that production of a significant portion of the DOC in natural watersheds occurs over a short time scale (less than 40 years). Because the time scales of DOC turnover and anthropogenic perturbations (i.e., changes in acidic deposition or climate) are comparable, the potential exists for anthropogenic activities to change DOC cycling and, consequently, the acid-base chemistry of waters and the mobility, toxicity, or persistence of metal or organic contaminants.

Both ${ }^{13} \mathrm{C}$ and ${ }^{14} \mathrm{C}$ indicate that processes affecting DOC in streams differ during low and high flow periods. Beaver ponds, although not net producers of DOC, modify the ${ }^{13} \mathrm{C}$ and ${ }^{14} \mathrm{C}$ composition of the exported $\mathrm{DOC}$, indicating internal DOC cycling.

$\Delta{ }^{14} \mathrm{C}$ measurements on DOC fractions indicate that aquatic humic substances are probably more refractory than aquatic fulvic acids. Comparison of ${ }^{14} \mathrm{C}$ activities in total DOC and humic substances suggest the presence of a rapidly cycling component not captured in the standard humic or fulvic separation method.

The low ${ }^{14} \mathrm{C}$ activity in shallow groundwaters compared to surface waters indicates that the groundwater DOC is not simply a small fraction of the total DOC that bypasses the DOC oxidation, sorption, and precipitation processes in the soil horizons but must be DOC that has undergone extensive cycling in the upper soil zone or aquifer.

Our ongoing research will continue to investigate the sources and transformation of DOC and assess the importance of DOC in lake carbon metabolism in differing natural forested watersheds.

Acknowledgments. J. Wills, M. English, and R. Elgood assisted in sample preparation and field work. D. Gardner and B. Hutchinson of the Dorset Research Centre, Ontario Ministry of the Environment, calculated the DOC and hydrologic mass balances. W. Wolfli and G. Bonani of the Tandem Accelerator Facility of the Institut für Mittelenergiephysik located at the ETH and operated by the Paul Scherrer Institute are thanked for facilitating ${ }^{14} \mathrm{C}$ analyses. $\mathrm{R}$. Elgood drafted the figures. Excellent criticism and valuable improvements on the manuscript were contributed by $M$. English, $L$. 
Wassenaar, and three anonymous reviewers. Funding was provided by NSERC and the Ontario Ministry of the Environment APIOS program.

\section{REFERENCES}

Baker, J. P., and C. L. Schofield, Aluminum toxicity to fish in acidic waters, Water Air Soil Pollut., 18, 289-309, 1982.

Bourbonniere, R. A., Distribution patterns of dissolved organic matter fractions in natural waters from eastern Canada, Geochim. Cosmochim. Acta, 53, 97-107, 1989.

Boutton, T. W., W. W. Wong, D. L. Hachey, L. S. Lee, M. P. Cabrera, and P. D. Klein, Comparison of quartz and pyrex tubes for combustion of organic samples for stable carbon isotope analysis, Anal. Chem., 55, 1832-1833, 1983.

Dankevy, S. N., S. L. Schiff, M. C. English, and P. J. Dillon, Groundwater flow and chemistry in a small acid-stressed subcatchment in the Canadian Shield, Proceedings of the NHRI Symposium on Groundwater Contamination, National Hydrologic Research Institute, Environment Canada, Saskatoon, Sask., in press, 1990.

Davis, R. B., D. S. Anderson, and F. Berge, Paleolimnological evidence that lake acidification is accompanied by loss of organic matter, Nature, 316, 436-438, 1985.

Deines, $\mathbf{P}$., The isotopic composition of reduced organic carbon, in Handbook of Environmental Isotope Geochemistry, vol. 1, edited by P. Fritz and J. Ch. Fontes, pp. 329-406, Elsevier, New York, 1980.

Devito, K. J., P. J. Dillon, and B. D. LaZerte, Phosphorus and nitrogen retention in five Precambrian Shield wetlands, Biogeochemistry, in press, 1990

Dillon, P. J., and L. A. Molot, The role of ammonium and nitrate retention in the acidification of lakes and forested catchments, Biogeochemistry, in press, 1990.

Dillon, P. J., D. S. Jeffries, W. A. Scheider, and N. D. Yan, Some aspects of acidification in southern Ontario, paper presented at the International Conference on the Ecological Impact of Acid Precipitation, SNSF project, Sandefjord, Norway, March 11-14, 1980.

Dillon, P. J., D. S. Jeffries, and W. A. Scheider, The use of calibrated lakes and watersheds for estimating point source, Water Air. Soil. Pollut., 18, 241-258, 1982.

Dillon, P. J., R. A. Reid, and E. de Groisbois, The rate of acidification of aquatic ecosystems in Ontario, Canada, Nature, $329,45-48,1987$.

Dillon, P. J., R. A. Lusis, R. A. Reid, and D. Yap, Ten-year trends in sulphate, nitrate and hydrogen deposition in central Ontario, Atmos. Environ., 22, 901-905, 1988.

Drever, J., The Geochemistry of Natural Waters, 437 pp., PrenticeHall, Englewood Cliffs, N.J., 1988.

Eshleman, K. N., and H. F. Hemond, The role of organic acids in the acid-base status of surface waters at Bickford Watershed, Massachusetts, Water Resour. Res., 21, 1503-1510, 1985.

Hedges, J. I., J. R. Ertel, P. Quay, P. M. Grootes, J. E. Richey, A. H. Devol, G. W. Farwell, F. W. Schmidt, and E. Salsti, Organic carbon-14 in the Amazon River system, Science, 231, 1129-1131, 1986.

Herczeg, A. L., W. S. Broecker, R. F. Anderson, S. L. Schiff, and D. W. Schindler, A new method for monitoring temporal trends in the acidity of freshwaters, Nature, $315,133,1985$.

Jeffries, D. S., and W. R. Snyder, Geology and geochemistry of the Muskoka-Haliburton study area, Data Rep. Dr 83/2, Dorset Research Centre, Dorset, Ont., Canada, 1983.

Kieser, W. E., R. P. Beuber, L. R. Kilius, H. W. Lee, and A. E. Litherland, ISOTRACE radiocarbon analysis-Equipment and procedures, Nucl. Instrum. Methods Phys. Res., Sect. B, 15, 718-721, 1986.

Kortelainen, P., and J. Mannio, The contribution of acidic organic anions to the ion balance of lake waters, in Acidification and Water Pathways, UNESCO Conference, Bolkesjo, Norway 4-5 May 1987, vol. II, pp. 229-238, Norwegian National Committee for Hydrology, Oslo, 1987.

Krug, E. C., and C. R. Frink, Acid rain on acid soil: A new perspective, Science, 221, 520-525, 1983.

LaZerte, B. D., and P. J. Dillon, Relative importance of anthropogenic versus natural sources of acidity in lakes and streams of central Ontario, Can. J. Fish. Aquat. Sci., 41, 1664-1677, 1984.
Leenheer, J. A., and E. W. D. Huffman, Analytical method for dissolved organic carbon fractionation, 16 pp., U.S. Geol. Surv. Water Resour. Invest., 79-4, 1979.

Manning, M. R., D. C. Lowe, W. H. Melhuish, R. J. Sparks, G. Wallace, C. A. M. Brenninkmeijer, and R. C. McGinnis, The use of radiocarbon measurements in atmospheric studies, Radiocarbon, 32, 37-58, 1990.

McNeely, R., Radiocarbon dating laboratory, GEOS, 17, 10-12, 1988.

Murphy, E. M., S. N. Davis, A. Long, D. Donahue, and A. J. T. Jull, ${ }^{14} \mathrm{C}$ in fractions of dissolved organic carbon in ground water, Nature, 337, 153-155, 1989a.

Murphy, E. M., S. N. Davis, and A. Long, Characterization and isotopic composition of organic and inorganic carbon in the Milk River Aquifer, Water Resour. Res., 25, 1893-1905, 1989 b.

O'Brien, B. J., and J. D. Stout, Movement and turnover of soil organic matter as indicated by carbon isotope measurements, Soil Biol. Biochem., 10, 309-317, 1978.

Ontario Ministry of the Environment, The 1987 performance report, water quality section, 400 pp., Dorset, Ont., 1989.

Paul, E. A., and J. A. Van Veen, The use of tracers to determine the dynamic nature of organic matter, Trans. Int. Cong. Soil Sci., llth, 3, 61-102, 1978.

Seip, H. M., R. Seip, P. J. Dillon, and E. deGroisbois, Model of sulphate concentration in a small stream in the Harp Lake catchment, Ontario, Can.J. Fish. Aquat. Sci., 42, 927-937, 1985.

Stuiver, M., and H. A. Polach, Discussion: Reporting of ${ }^{14} \mathrm{C}$ data, Radiocarbon, 19, 355-363, 1977.

Stumm, W., and J. Morgan, Aquatic Chemistry, 780 pp., John Wiley, New York, 1981.

Suter, M., R. Balzer, G. Bonani, M. Nessi, C. Stoller, W. Wolfli, M. Andree, J. Beer, and H. Oeschger, Precision measurements of rare radioisotopes with a tandem Van-de-Graaf accelerator, IEEE Trans. Nucl. Sci., NS-30, 1528-1531, 1983.

Tans, P. P., A compilation of bomb ${ }^{14} \mathrm{C}$ data for use in global carbon cycle model calculations, in Scope 16. Carbon Cycle Modeling, edited by B. Bolin, pp. 136-146, John Wiley, New York, 1981.

Thurman, E. M., Determination of aquatic humic substances in natural waters, pp. 47-52, U.S. Geol. Surv. Water Supply Pap. $2262,1984$.

Thurman, E. M., Humic substances in groundwater, in Humic Substances in Soil, Sediment and Water, edited by G. R. Aiken et al., 760 pp., John Wiley, New York, 1985.

Thurman, E. M., and R. L. Malcolm, Preparative isolation of aquatic humic substances, Environ. Sci. Technol., 15, 463-466, 1981.

Wallis, P. M., H. B. N. Hynes, and S. A. Telang, The importance of groundwater in the transportation of allochthonous dissolved organic matter to streams draining a small mountain basin, Hydrobiologica, 79, 77-90, 1981.

Wassenaar, L. I., Geochemistry, isotopic composition, origin and role of dissolved organic carbon fractions in groundwater systems, Ph.D. thesis, Dep. of Earth Sci., Univ. of Waterloo, Ont., Canada, 1990.

Wassenaar, L. I., R. Aravena, P. Fritz, and J. F. Barker, Isotopic composition $\left({ }^{13} \mathrm{C},{ }^{14} \mathrm{C}\right.$ and $\left.{ }^{2} \mathrm{H}\right)$ and geochemistry of aquatic humic substances from groundwater, Org. Geochem., in press, 1990.

Williams, P. M., and R. M. Druffel, Radiocarbon in dissolved organic matter in the central North Pacific Ocean, Nature, 330 , 246-248, 1987.

Williams, P. M., H. Oescheger, and P. Kinney, Natural radiocarbon activity of the dissolved organic carbon in the North-east Pacific Ocean, Nature, 224, 256-258, 1967.

R. Aravena and S. L. Schiff, Waterloo Centre for Groundwater Research and The Department of Earth Sciences, University of Waterloo, Waterloo, Ontario, Canada N2L 3G1.

P. J. Dillon, Dorset Research Centre, Ontario Ministry of the Environment, Dorset, Ontario, Canada P0A 1E0.

S. E. Trumbore, Center for Accelerator Mass Spectrometry, Lawrence Livermore National Laboratories, Livermore, CA 94550.

(Received November 30, 1989; revised June 22, 1990; accepted July 3, 1990.) 